1990. "The Southern European Examples of Democratization: Six Lessons for Latin America." Government and Opposition 25(1):68-84.

-1 1991. "Constitutional Choices for New Democracies." Journal of Democracy 2(1):72-84.

Lijphart, Arend, and M.M.L. Crepaz. 1991. "Corporatism and Consensus Democracy in Eighteen Countries: Conceptual and Empirical Linkages." British Journal of Political Science 21(2):235-46.

Lijphart, Arend. 1991. "Majority Rule in Theory and Practice: The Tenacity of a Flawed Paradigm.' International Social Science Review 129:483-93.

- ed. 1992. Parliamentary versus Presidential Government. Oxford: Oxford University Press.

- 1992. "Democratization and Constitutional Choices in Czecho-Slovakia, Hungary, and Poland, 1989-1991," Journal of Theoretical Politics 4(2):207-23. . 1994. "Presidentialism and Majoritarian Democracy: Theoretical Observations" in The Failure of Presidential Democracy, eds. Juan J. Linz and Arturo Valenzuela. Baltimore: Johns Hopkins University Press.

-1994. Electoral Systems and Party Systems: A Study of Twenty-Seven Democracies, 1945-1990. Oxford: Oxford University Press.

- 1994. "Democracies: Forms, Performance, and Constitutional Engineering.' European Journal of Political Research 25(1): $1-17$ 1994. “On S.E. Finer's Electoral Theory." Goverment and Opposition 29(5):623-36.

Lijphart, Arend. 1995. "The Virtues of Parliamentarism: But Which Kind of Parliamentarism?"' In Politics, Society, and Democracy: Comparative Studies, eds. H.E. Chehabi and Alfred Stepan. Boulder, CO: Westview Press.

- N.d. "Back to Basics: Who Really Practices Majority Rule?" In Democracy's Victory and Crisis, ed. Axel Hadenius. Cambridge University Press. Forthcoming.

- N.d. "About Peripheries, Centers, and Other Autobiographical Reflections." In The Intellectual Autobiography of Comparative European Politics, ed. Hans Daalder. London: Frances Pinter. Forthcoming.

- N.d. "SNTV and STV Compared: Their Political Consequences in Japan, Ireland, and Malta." In Elections in Japan, Korea, and Taiwan Under the Single Non-Transferable Vote: The Comparative Study of an Embedded Institution, eds. Bernard Grofman, Sung-Chull Lee, Edwin Winckler, and Brian Woodall. Ann Arbor: University of Michigan Press. Forthcoming.

Taylor, P.J., and Arend Lijphart. 1985. "Proportional Tenure vs. Proportional Representation: Introducing a New Debate." European Journal of Political Re search 13(4):387-99.

\section{The Windy City Favors the 1995 Annual Meeting}

At its new location in the Chicago Hilton and Towers, the 1995 Annual Meeting drew record-setting crowds second only to the exceptional 1994 New York meeting. With 5,559 attendees in 1995, the meeting surpassed the 1993 Washington meeting $[5,151]$ and outshone the 1992 meeting [4,998], the last held in Chicago.

Credit for the attractiveness of the meeting to APSA members is due to the Program Committee cochairs, Mary Fainsod Katzenstein of Cornell University and Peter J. Katzenstein of Cornell University, and the 46 division chairs of the Program Committee, as well as the 46 Related Group organizers. Panels and roundtables organized by the Program Committee, Related Groups, and APSA generated a meeting of 650 panels. It is possible to appreciate the size and complexity of the APSA meeting by comparing it to the numbers of panels offered at the annual meetings of our sister associations. Using 1994 data, and an APSA meeting of 620 panels over the course of 3.5 days, Anthropology's meeting offered 372 panels spread over 4.5 days; Geography, 560 panels over 4 days; History, 148 panels over 3 days; and Sociology, 386 panels over 5 days.

\section{Mary Katzenstein and Peter} Katzenstein selected Liberalism at Century's End as the meeting's theme. Its relevance is attested to by the fact that 8 of the 10 most highly attended panels were organized around the theme. The largest single session being the roundtable, The End of Liberalism? Presidential Leadership and the 1994 Midterm Elections organized by Stanley Renshon of the City University of New York in the prosearch chaired by Lyn Ragsdale of the University of Arizona. lights were Sidney Verba's Presidential Address, The Citizen as Respondent: Surveys, Representation, and American Democracy, to be featured in the March issue of the American Political Science Review. Other notable addresses include the first Ithiel de Sola Pool Lecture by Robert D. Putnam of Harvard University, Tuning In, Tuning Out: The Strange Disappearance of Social Capital in America [featured in this issue of $P S]$, and the John Gaus Lecture by Charles E. Lindblom of Yale University, Market gram division on presidency re-

Among the other program high-

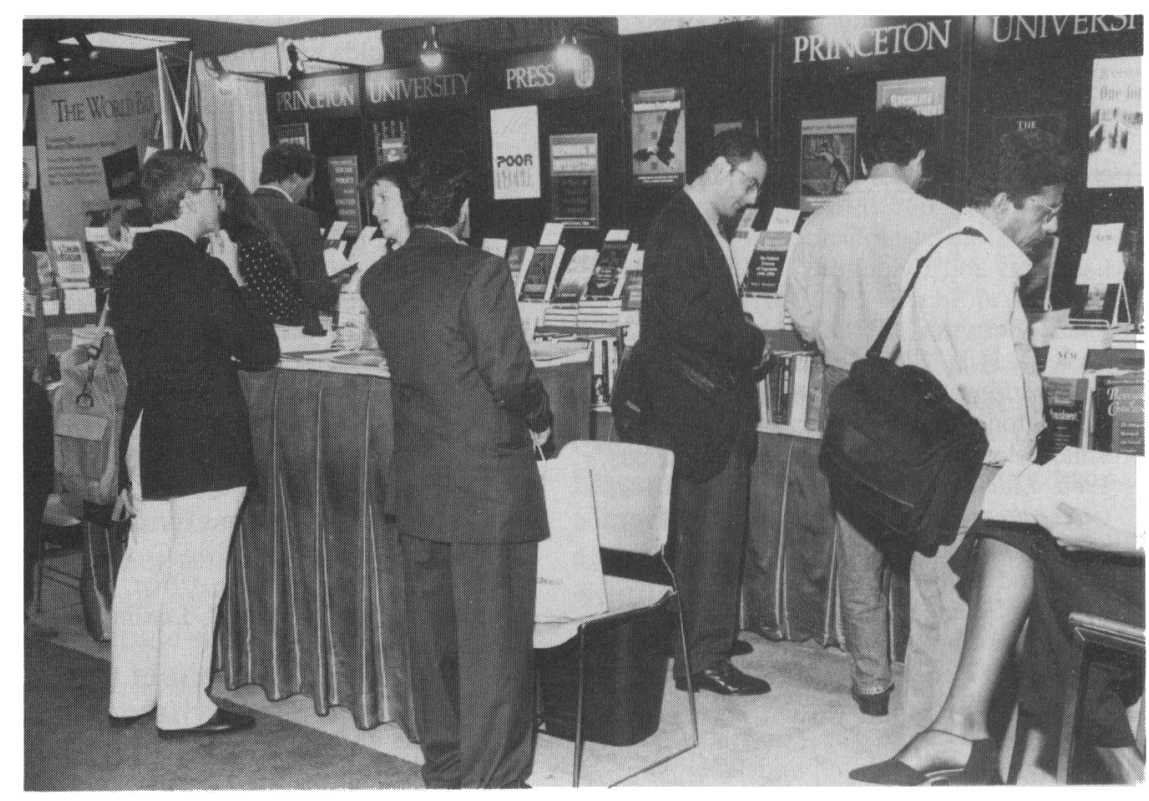

APSA Book Exhibit-the largest such exhibit in the world 


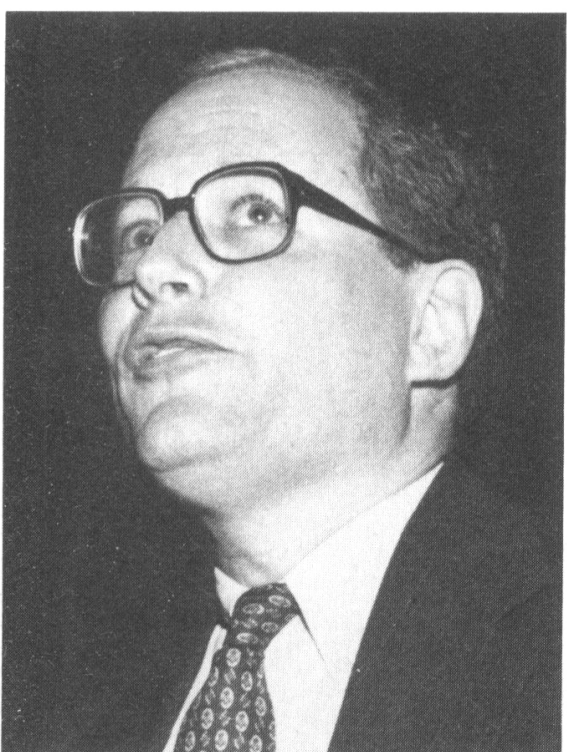

William Kristol

and Democracy-Obliquely [also featured in this issue of $P S$ ].

The 1995 Meeting also successfully integrated a variety of new or improved offerings: pre-convention short courses, a departmental chairs conference, "Hyde Park" sessions, poster sessions, and a record number of receptions and affiliated functions.

\section{Poster Sessions}

A poster session was organized by the Public Policy Division, chaired by David J. Webber of the University of Missouri, Columbia. Poster sessions offer a unique visual aid to paper presenters and a one-on-one opportunity for attendees to discuss the work presented. Plans are already afoot for several program divisions to offer poster sessions at the 1996 Annual Meeting in San Francisco.

\section{Hyde Park Sessions}

First introduced at the 1993 Annual Meeting, "Hyde Park" sessions enlivened the 1995 meeting. Three sessions were presented. How Angry is the Electorate? was moderated by Catherine E. Rudder of the APSA and included E.J. Dionne Jr. of the Washington Post, author of Why Americans Hate
Politics [1991]; To Die for What?

Good and Bad Arguments for Using American Troops in the PostCold War World, moderated by Peter Gourevitch of the University of California, San Diego; and $I s$ There a Right to Discriminate Against Gays and Lesbians?, moderated by Martin Shapiro of the University of California, Berkeley. The sessions record audiences [75100].

\section{Conference for Departmental Chairs}

The fourth annual Conference for Departmental Chairs offered sessions on sources of data on political science faculty and programs; preparing for and evaluating under- graduate teaching; organizing an external departmental review; and subtle discrimination in academic life. Participation in the Chairs Conference increases yearly as the Association's Departmental Services Committee responds to the need to assist political science chairs with information on the discipline and developments in higher education.

The 1995 sessions were well attended and provided information to assist political science chairpersons in resource acquisition and allocation, planning and evaluating programs, and constructing collegial, productive climates. The fall issue of "For the Chair. ..." will feature summaries of the Chairs Conference Session. This newsletter is distributed directly to political sci-

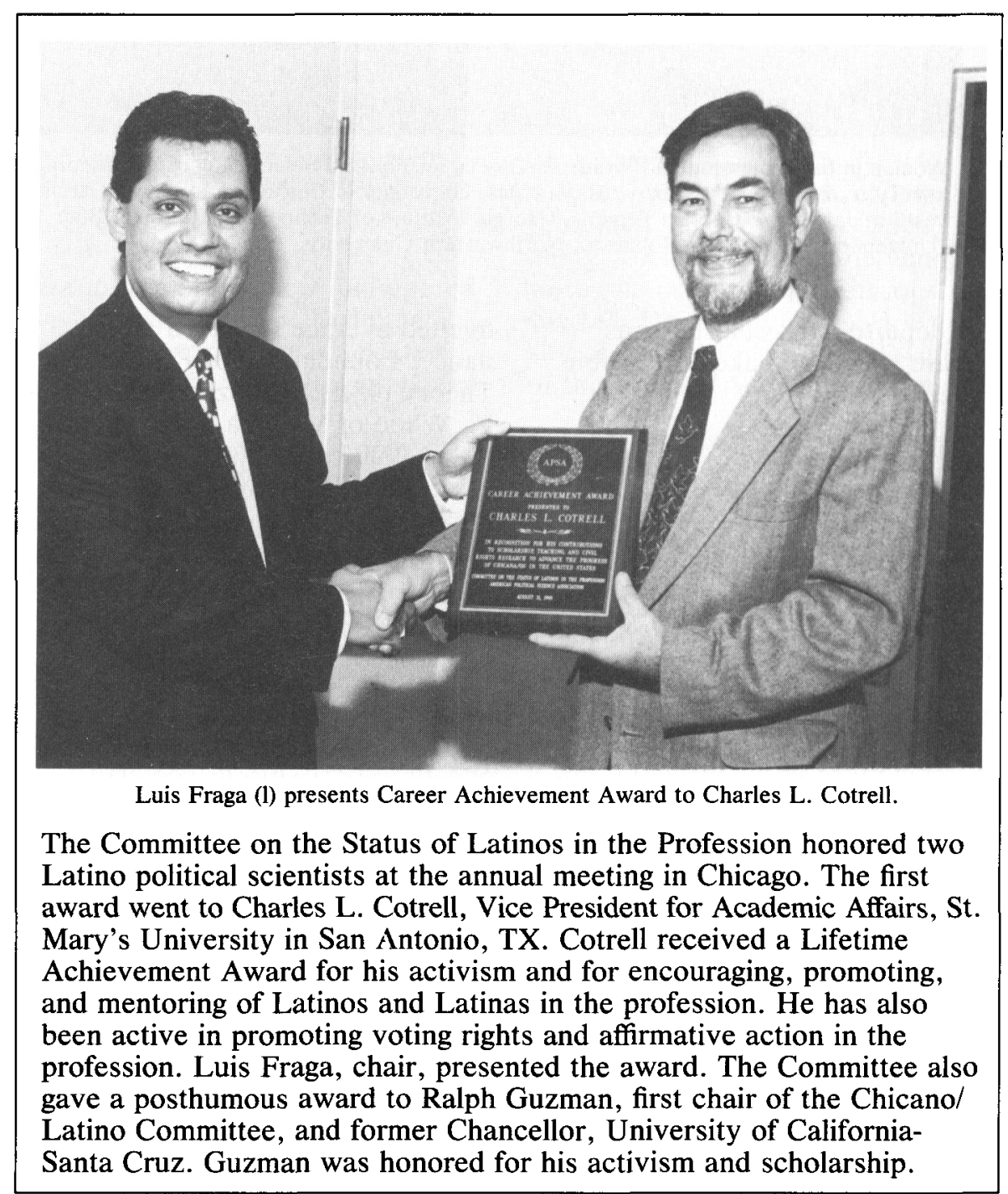




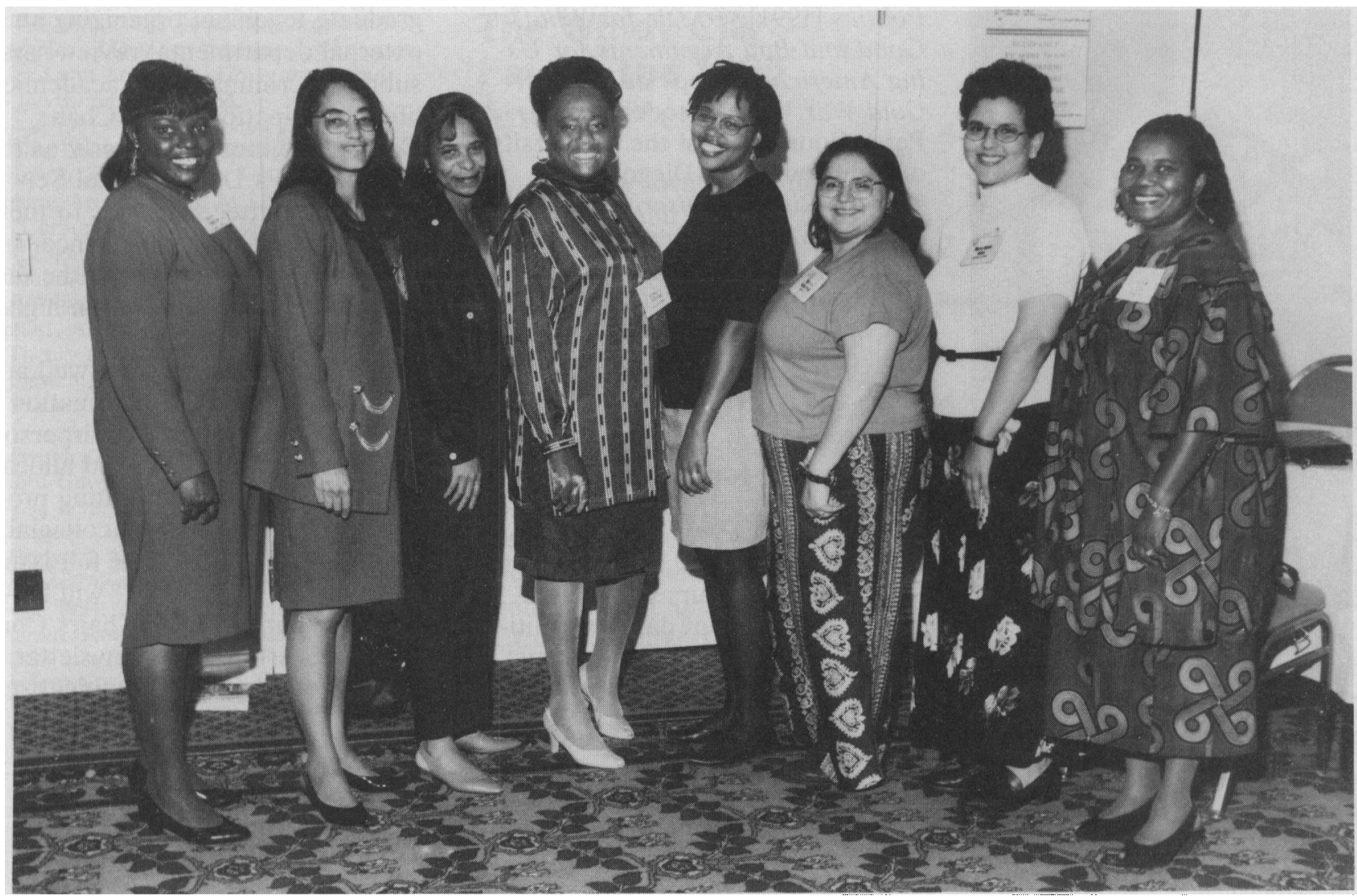

Black Women in the Profession and Women's Caucus for Political Science Reception honoring black women in the profession. From right to left: Katie Tyler, Brandeis University; Maria Niles, University of Chicago; Patricia A. Garcia-Monet, Rice University; Michelle Boyd,

Northwestern University; Georgia Persons, Georgia Institute of Technology; LaVonna Blair, Rice University; Toni-Michelle Travis, George Mason University; and Tabatha Robinson, Northwestern University.

ence departmental chairpersons who are asked to make it available to their faculty.

\section{Related Groups}

Always an integral and exciting element of the Annual Meeting, Related Group Organizers met with APSA officers and staff for the first of what will become annual events. The informal session offered Related Group organizers an open forum to address problems and opportunities faced when putting together their group programs.

\section{Large Audiences Drawn to 1995 Panels}

Despite sunny skies, mild temperatures, and the Chicago Jazz Festival, over 650 panels at the 1995 Annual Meeting attracted consistently high attendance.

Among the program divisions, five led average weighted attendance: Foundations of Political Theory [45.1] organized by Stephen K. White of Virginia Tech; International Political Economy [42.9] organized by Louis W. Pauly of the University of Toronto; Politics and Literature [42.3] organized by Diana J. Schaub of Loyola College; Elections and Electoral Behavior [38.9] organized by Michael B. MacKuen of the University of Missouri, St. Louis; and Political Economy [37.1] organized by Barry Weingast of Stanford University.

Among groups of panels organized by related groups, those drawing the highest attendance included: the Association for the Study of Nationalities [44.2] organized by Lowell W. Barrington of the University of Michigan; The Claremont Institute [34.1] organized by Douglas Jeffrey and Julie A. Kessler; Conference Group on the Middle East [32.1] organized by Louis J. Cantori at the University of Maryland, Baltimore County; and the Eric Voegelin Society [31.9] organized by Ellis Sandoz of Louisiana State University.

The theme of the meeting, Liberalism at Century's End, was the topic at eight of the ten most highly attended panels. The largest audience recorded [269] was drawn by a roundtable, The End of Liberalism? Presidential Leadership and the 1994 Midterm Elections. The roundtable featured Stanley Renshon of the City University of New York, William Kristol, Editor of The Standard, and Stephen Wayne of Georgetown University.

Second in attendance was the roundtable, Looking Back on Theodore Lowi's The End of Liberalism, chaired by Stephen Skowronek of Yale University. Participants included Robert Dahl of Yale University, Margaret Weir of the Brookings Institution, Ira Katznelson of Columbia University, Karen Orren of UCLA, and Theodore Lowi of Cornell University.

The largest audience at a panel 